\title{
Technological advances: what hope for colorectal cancer?
}

\author{
Type of article: Review \\ Boumediene Elhabachi; Mama Sidelmrabet Ben Brahim \\ Faculty of medicine University of Sidi Bel Abbes, Algeria \\ CHU Dr Hassani A.E.K, Algeria
}

\begin{abstract}
Introduction: Colorectal cancers rank third in all cancers. Mass screening has proven effectiveness by significantly reducing incidence and mortality. If optical colonoscopy is the reference exam, virtual colonoscopy is an alternative of choice. We evaluate its first-line position in screening, following technological progress.

Methods: We used PubMed's electronic search data from 2010. Among the 100 most consulted articles, have been studied those in English-language and which looked at screening in the population at average risk aged between 50 and 75 years, asymptomatic and dealing with optical and virtual colonoscopy. Studies in the symptomatic, high-risk, or very high-risk population or for diagnostic purposes were excluded.

Results: in the USA, studies confirm the trend towards a decrease in incidence and mortality by colorectal cancers, shifting from 56.7 per 100,000 and 23.6 deaths respectively in 1992 to 36.5 per 100,000 and 14 deaths in 2015, thanks to the means of screening including the endoscopy. Although optical colonoscopy is the standard exam, virtual colonoscopy, with a specificity of $90 \%$ and a sensitivity of $85 \%$, is becoming more and more a first-line means of screening for colorectal cancers.

Conclusion: Thus, first-line endoscopic screening has proved its effectiveness in reducing morbidity and mortality by this cancer. However, the virtual endoscopy chosen by the National Comprehensive Cancer Network as a means of screening will undoubtedly constitute a strategy for the future, particularly in developing countries.

Keywords: colorectal cancers; screening; optical colonoscopy; virtual colonoscopy.

Corresponding author:Boumediene Elhabachi Faculty of medicine University of Sidi Bel Abbes, Algeria, email: b.elhabachi@yahoo.fr.

Received: 23 February 2019, Accepted: 29 Mars, 2019, English editing 29 Mars, 2019, Published 01 April 2019.

Screened by iThenticate..C2017-2019 KNOWLEDGE KINGDOM PUBLISHING.
\end{abstract}

\section{INTRODUCTION}

With more than 1 million diagnosed cases per year worldwide and a mortality of more than 500,000 [1], colorectal cancers (CRC) are a public health problem [2]. They are sporadic in 70 to $80 \%$ of cases, occur in a family context in 20 to $30 \%$ [3] of cases and are linked to a genetic predisposition in 5 to $10 \%$ of cases [4].

Depending on the risk of developing CRC [5-8], we distinguish the group at:

- Average risk:[9] to which belongs any person over the age of 50, without any other associated risk factor of CRC [10].

- High risk: higher than 5\% throughout life and in which we find people with personal or family history of adenoma or CRC [11] as well as people with chronic inflammatory bowel disease [12-15] (chronic inflammatory rectocolitis or Crohn's disease).

- Very high risk: characterized by genetic mutations $[8,16]$ and in this case it is hereditary cancers which represent $5 \%$ of all CRC [17].

While colonoscopy surveillance does not pose an indication problem for high and very high risk groups [6, 7], this is not the case for the average risk group [18]. Advances in technology have enabled the development of numerous means 
including high definition endoscopy coupled with virtual chromoendoscopy and virtual colonoscopy, which must be optimized to obtain the best results in terms of lives saved.

\section{Methods}

We studied the 100 most cited articles and the 20 most cited articles per year [19]. In order to reinforce our study and not to ignore recent publications, which are necessarily less cited and whose results are a reflection of technological progress, we conducted a search using the Pubmed database over the period from 2010 through 31 January 2019, using the keywords: "colorectal screening", "Colonography, Computed Tomo-graphy," "virtual colonoscopy," "optical colonoscopy". We studied the recommendations and their justifications of the learned society NCCN [6, 7] and US Preventive Services Task Force [10, 20].

- Inclusion criteria, this study included articles in the English language that deal exclusively with colorectal screening in the general population aged 50 to 75 years, in both sexes, with no family or personal history of CRC or adenoma, or personal history of inflammatory bowel disease. These studies, which may be comparative, must necessarily deal with the so-called direct screening means, structural or endoscopic, namely virtual and optical colonoscopy.

- Exclusion criteria were excluded studies that deal with the diagnosis of $\mathrm{CRC}$ or symptomatic subjects as well as those concerning subjects under 50 years old, in the case of a contraindication of a means of screening, and in the case where a study does not evaluate a tool as a means of screening. All studies evaluating screening in the high or very high risk population were excluded.

- Studies dealing with the diagnosis of CRC.

- Studies concerning subjects under 50 years old.

- Studies not dealing with the evaluation of a tool as a means of screening.

- Studies evaluating screening in the high or very high risk population.

- In cases of contraindication of a means of screening.

\section{MEANS}

\section{Endoscopy}

Optical colonoscopy (OC) explores the entire colon and rectum.

Rectosigmoidoscopy allows endoscopic examination of the rectum and left colon (up to the left colic angle), the development site of $3 / 4$ of CRC. Endoscopy reduces CRC mortality through early diagnosis [21] especially the detection of precancerous lesions that are polyps [11] (by resecting them preventing their progression to cancer). OC has allowed the USA to reduce the incidence of CRC [17] from 76 to $90 \%$ [22] in a population with endoscopy. This reduction is significant for left lesions less for right colon cancers [23, 24].

The $\mathrm{CO}$ with dual diagnostic and therapeutic advantage [9] must first detect a polyp and, in a second time, characterize it.

The detection of polyps can be difficult because of:

- Their size, they can be hidden by colic folds. 
- The appearance of the polyp. A polyp can be pediculated projecting into the light or sessile based implantation more or less wide or even plan aspect and in this case the detection is even more difficult.

Modern endoscopes make it possible to obtain high definition images "HD" $(2,000,000$ pixels). Some studies have not found a difference in the detection rate of adenomas (DRA) or polyps (DRP) between standard colonoscopy and HD [25, 26].

A multicenter study showed that DRA was higher with HD colonoscopies, especially for flat adenomas and right colon [27]. White light with HD images seems to increase the DRA by 3.5\% [28]. In order to increase the detection rate, have been made available to endoscopists:

$>$ Coloscopes with enlarged vision:

- The Full-Spectrum Endoscopy system has the particularity of having 3 cameras which allows a $330^{\circ}$ angle of view compared to 140 to $170{ }^{\circ}$ for the other endoscopes and this system seems interesting for the detection of polyps behind the folds and to the internal side of the colic angles with less adenoma missed [29].

- The Extra-Wide-Angle-View Colonoscope with wide field of view thanks to two cameras placed on the sides $\left(144-232^{\circ}\right)$ and one at the end of the endoscope $\left(140^{\circ}\right)$ and this system seems to improve the DRA by $22 \%[30,31]$.

- The third eye or Third Eye Retroscope. The retro vision is often used in the rectum to analyze the anal area and not to miss lesion at the bottom caecal [32].

$>$ Endoscopes with balloon system.

$>$ Colonoscopy assisted by cap.

All polyps do not degenerate $[8,33,34]$ and the risk is related to the histological type, namely adenomatous polyps with villous component and serrated polyps (the latter predominate in the right colon and are usually sessile), the presence of severe dysplasia, and size of the polyp [35, 36]. Hyperplastic polyps of small size (less than $1 \mathrm{~cm}$ ) especially those located in the rectum or sigmoid pose no risk of malignant transformation [7, 37].

Very innovative approaches have been made possible by technological progress. In the age of modern technology and in the case of CRC the purpose of the examinations is to detect polyps at risk and resect them. This supposes that we can recognize them. We can also remove without analyzing the (so no pathologic study) polyps that are certainly safe with a cost saving [38]. This is the so-called DISCARD strategy of "Detect InSpect ChAracterize Resect and Discard Or "Characterize, Resect, and Leave". This strategy is feasible [39] and safe [40] because we can count on modern technology. It is possible to recognize polyps certainly safe, hyperplastic type, small and localized in the rectum or sigmoid and abandon them which allows even more economy. This is the so-called strategy: Characterize and Leave or "Detect-and-leave" or "Detect-and-disregard".

To better analyze the colonic surface and find the polyps we have the indigo carmine vital staining or chromoendoscopy [41] and virtual chromoendoscopy using integrated systems including NBI (Narrow Band Imaging) [42-44]. The principle of virtual chromoendoscopy relies on the exploitation of the physical and optical properties of certain specific bands of the white light spectrum. 
The endoscopy of the modern era must characterize the polyps detected hence the notion of optical biopsy [45]. If for the detection of polyps, the expertise of the operator remains the essential element and although the detection rate is improved by HD modern endoscopes including the right, it should be specified that the characterization which consists in predicting the histological diagnosis of polyps has, with the NBI and without Zoom, a diagnostic accuracy of 96 to $98 \%$ for polyps less than $1 \mathrm{~cm}[46,47]$.

The high magnification optical Zoom up to X60 or even X400 allows a microscopic scale analysis of the mucosal surface indeed subcellular analysis (X1000) by endo-microscopy by mini probe allowing a histological analysis in real time [48, 49]. In combination with the NBI the diagnostic accuracy approaches the histopathology [49].

The NBI associated with a high optical magnification used by Japanese teams allows a diagnostic accuracy higher than $96 \%$ and a negative predictive value (NPV) of $96 \%$ [50].

The classification Nice [51] (N BI I nternational C olorectal E ndoscopic) is widely used [52]. It is based on NBI analysis without zooming the color of the polyp, the presence of vessels (and their diameter) and the pattern of the mucosa. It makes it possible to distinguish the polyps hyperplastic (type 1), adenomas (type 2) and infiltrating cancers s (type 3 ).

Virtual colonoscopy or Computed tomography colonography (CTC) :

It is a colon scan with $\mathrm{CO} 2$ insufflation that can be performed without intravenous injection. This examination whose performance improves in parallel with technological advances has shown since few years $90 \%$ of polyps larger than $1 \mathrm{~cm}$ found by optical colonoscopy (OC), discovered some lesions not perceived by $\mathrm{CO}$, for a total a sensitivity and a specificity of $90 \%$ for polyps larger than $1 \mathrm{~cm}$ [53-55]. The CTC is very specific even for small polyps [56] but the sensitivity varies widely according to the studies [20]. These differences could be explained by the types of scanners, detectors, the thickness of the cuts [57], the terms of acquisition and are based on readers [58] and their expertise [59, 60]. Overall, the CTC has excellent sensitivity and specificity for polyps $>10 \mathrm{~mm}$ in particular adenomatous and early cancers, hence its place in screening [53-55, 61-65] even if the sensitivity decreases with the size of the polyp [66-69]. The detection of polyps is enhanced with computer assistance (Computer- Aided polyp Detection (CAD) program) [70] especially for small polyps [71]. Interpretation time is reduced $[72,73]$ and detection seems comparable to that of OC according to some studies for adenomatous polyps $>$ or $=8 \mathrm{~mm}$ [74]. However flat polyps are difficult to detect [75] but this should not be an obstacle for the CTC as a means of screening including first-line [76]. This assistance does not replace the expertise that the radiologist must have [59] whose experience in gastrointestinal radiology is an undeniable advantage that can not be bridged by the single learning curve [77]. The interpretation is done by a radiologist who has the required expertise [9] the consequences of inadequate interpretation can be severe. CTC screening adherence [78] is significantly higher compared to OC, which probably identifies more polyps per 100 people. The diagnostic performance of advanced neoplasia per 100 participants is equivalent, which justifies the use of 
the both means of screening in the average-risk population [79]. Indeed OC remains the reference exam and the most used in the USA [80] and whose sensitivity and specificity are higher compared to the CTC [81]. Higher CTC participation rate [82] fills this difference globally leading to a similar detection of advanced neoplasias [83, 84].

The CTC is sensitive, especially after colon preparation even at minima [85] and ingestion of contrast product (gastrographine) which can be sufficient in itself for colonic preparation [86]. Currently even in low doses that do not alter its sensitivity [87] CTC does not require rigorous preparation of the colon [88]. As the prevalence of CRC is low (3.5 to $4.5 \%$ ), a first-line CTC is desirable to avoid the complications of negative or white OC [89].

The detection rate by CTC for first-line screening is equivalent to the one of optical colonoscopy but the rate of complications and polypectomy is lower, which justifies the use of CTC as a means of screening and OC as a therapeutic means[90]. The complications of CTC are rare, especially the perforations that must be feared in elderly people with concomitant colic diseases [91].

The good negative predictive value of the CTC must reduce the indications of OC thus reducing the inconvenience of OC screening and cost [61, 92, 93]. It has a good concordance with the OC [92], is an effective option, safe, affordable, available, repeatable, fast and cost effective for colorectal cancer screening [94], that is why it was proposed in 2018 as a means of first-line screening [7, 83, 95].

It should be kept in mind that the detection rate of serrated polyps at risk is significantly higher for OC (facilitated by chromoendoscopy) compared with CTC (facilitated by contrast labeling) [96, 97].

Extra colic discoveries can be important [98, 99], beneficial but cause additional costs [100] that can be amortized by the management of serious illnesses [101].

It could cost up to $50 \%$ cheaper than the $\mathrm{OC}$ if its indications became broader to meet demand [102] and currently, compared to colonoscopy, its cost seems competitive $[102,103]$.

CTC allows better localization of lesions, which is important for surgery [104]. It has been an important part of colorectal exploration for more than ten years [105, 106]. There are currently wider indications for screening and first-line prevention of CRC [7, 106].

If for polyps of more than $1 \mathrm{~cm}$ discovered in CTC the indication of colonoscopy is certain, it will be more mitigated for polyps of 6 to $9 \mathrm{~mm}$. Exploration and polypectomy are required for many polyps but for one or two polyps 6 to $9 \mathrm{~mm}$, CTC control is possible because $38 \%$ of these polyps remain stable, $27 \%$ regress and only $35 \%$ become advanced [107]. In comparison with other screening techniques, virtual colonoscopy offers a safe option especially useful when colonoscopy is contraindicated [108].

\section{Stool Tests - Stool-Based Tests}

These tests are exclusively reserved for screening in the so-called average risk asymptomatic population. They consist of looking for occult blood in the stool by guaiac test or by immunological test and looking for alterations of the abnormal exfoliated DNA. These tests are not invasive and does not require any preparation. 


\section{Tests for occult blood tests in the stool}

Two tests are available namely to find the occult blood in the stool by guaiac test and by immunological test.

The guaiac test (Hemoccult II ${ }^{\circledR}$ test and Hemoccult II Sensa test)

This gFOBT test "Fecal Occult Blood Test", detects the heme via a peroxidase reaction.

The Hemoccult II ${ }^{\circledR}$ and Hemoccult II Sensa tests are simple, inexpensive, painless, reproducible, reliable and validated, thus meeting the criteria necessary for a mass screening test.

In France the Hemoccult II test would detect only $20 \%$ of advanced polyps, 1 out of 2 cancers, decrease mortality by 16 to $18 \%$ at 10 years with a national observance of only $30 \%$ [109].

The Hemoccult-SENSA test is based on the Hemoccult II test on the detection of heme via a peroxidase reaction. It has a sensitivity of 64 to $80 \%$ for CRC but lower for adenomas [110].

These tests have the disadvantage of not detecting tumors that bleed very little, intermittently or not at all. The false positives are due to the positive reaction with the nonhuman heme (food) and the blood of gastrointestinal origin thus upper tract [7].

The immunological test "Fecal immunochemical tests (FITs)"

This test (iFOBT) detects the presence of human globin through the use of antiglobin monoclonal or polyclonal antibodies [9]. It has advantages over the Guaiac test [111] and is superior to it in terms of participation rate, positivity rate and detection rate [112-114]. It is specific for blood of colic origin, ruling out false positives for bleeding from the upper digestive tract [110], globin is rapidly digested in the stomach and the small intestine. This test allows an automated and reproducible reading.

Screening combining a positive FITs (iFOBT) test and colonoscopy allows the detection of 2 to 2.5 times more cancers and 3 to 4 times more advanced adenomas than the combination of a positive Guaiac test and colonoscopy [18]. The detection of cancer in-situ and stages I and II would be $71 \%$ whereas it is $55 \%$ for the Gaïac test; A test (FIT) is significantly superior to the guaiac test as a screening test in the average-risk population $[115,116]$ and should replace the gFOBT [110]. Screening by (FIT) leads to a reduction in mortality and the incidence of CRC $[117,118]$.

The gFOBT and iFOBT tests should not be used individually and certainly not in symptomatic people.

\section{The abnormal DNA analysis test in the stool}

The identification of abnormal DNA in the stool is a method of early diagnosis of colorectal cancer through searching for the APC gene mutation $[6,7,18]$. These are molecular tests. This method, certainly very promising in the future, is not considered to date as a well codified screening method [7].

\section{Non invasive screening by the Septin-9 test}

The SEPT9 gene codes for the SEPT9 protein. These proteins control cell growth and prevent uncontrolled divisions. The SEPT9 gene is considered a tumor suppressor [119]. Hypermethylation can occur in the promising gene and 
silencing it [119]. Epi pro Colon ${ }^{\circledR} 2.0$ (Second Generation Test) allows the detection at the plasma level of methylated septin9[120]. The presence in the plasma of methylated septin9 is a bio-marker of the risk of neoplastic colic [121124]. A positive test indicates a risk of CRC and an optical colonoscopy is recommended [125]. The sensitivity of the SEPT9 test would be equivalent to that of FIT but its specificity would be lower [126]. The sensitivity of SEPT9 for advanced adenomas would be lower compared to FIT [127]. The combination of tests is increasingly used in CRC screening. The FIT test associated with SEPT9 increases sensitivity and specificity [125]. This test was approved in 2016 by the FDA for CRC screening and the NCCN estimates that its sensitivity and specificity are lower than those of other tests [7].

\section{MR Colonography}

Studies on colo-MRI for screening are limited. One study showed a sensitivity and specificity greater than $75 \%$ for adenomas and cancers but which remain lower than those of colonoscopy [128]. Lack of equipment and cost would be unhelpful factors for this technique in screening and prevention [18].

\section{Discussion :}

Colorectal cancers mainly develop in subjects over 50 years of age who have no known risk factors $[9,10,20]$. Mass screening is aimed at this population aged 50 to 75 years $[5-7,10,20,80]$. Fecal occult blood testing (Hemoccult II, Hemoccult SENSA or FIT) reduced CRC mortality [17, 129].

People screened in the US, where endoscopy is the primary means of screening and prevention, have a reduction in CRC estimated between 76 and $90 \%$ [22, 130].

Mass screening is a public health action, not an individual one. People at high or very high risk are excluded from mass screening and must be individually screened by optical colonoscopy according to the recommendations of learned societies $[6,7,10,20]$.

In the USA, screening is done in different ways. Flexible Sigmoidoscopy [23, 131] and OC have both reduced CRC mortality [132]. Virtual colonoscopy was introduced in 2018 as a means of first-line screening [7]. Overall CTC is not as sensitive and specific as $\mathrm{CO}$ but can be used for screening in the average risk population [133] because effective enough.

American recommendations include colonoscopy every 10 years, fecal occult blood test by annual immunohistochemical test (FIT), a 10-year Sigmoidoscopy coupled with annual FIT and virtual colonoscopy (CTC) every 5 years in subjects aged 50 to 75 years $[6,7,20,134]$. These processes offer the same survival benefit in a years and a benefit ratio - equivalent risk [7, 134] in the case of screening. The CTC is better accepted by those screened and found to be less painful [135]. Both CTC and flexible Sigmoidoscopy are well accepted for CRC screening, but reduced discomfort associated with colonic preparation may improve participation in CTC screening [136, 137]. Indeed, the inconvenience of the examination and the disadvantages of the preparation are cited as the main 
reasons for refusal of screening [138]. The preference of the CTC is related to the absence of sedation, the speed of the procedure and the least physical constraint [78]. Unfortunately, this examination remains underutilized while it represents an ideal balance between the minimum invasiveness and the performance [139]. The CTC can be an excellent exam that filters the persons with a good health economy avoiding negative colonoscopies and their complications although rare and by systematizing small diminutive polyps $(<6 \mathrm{~mm})$ without even taking them on the record [140, 141]. Regarding cost, CTC like other means is more cost effective than lack of screening $[142,143]$ and in the USA, with $75 \%$ compliance OC and CTC may reduce the incidence of CCR 46 to 54\% [144] which represents an immense health economy. In addition, the CTC screening every 5 years is, according to a study, more effective than the OC every ten years [143]. The CTC is a relevant test that continues to develop to provide a high diagnostic accuracy that will make the examination cost-competitive with respect to OC [143]. Indeed, the more the subjects are referred to the OC after CTC and the more the advantage is to the OC and even to equal sensitivity the advantage remains for the OC [144]. Given these data, regarding the difficulty of proposing blood tests in the stool in developing countries and given the problems of sensitivity and specificity of these tests, which, in case of false positive, lead to white OC. Having regarding to the impossibility to offer out hand a screening by OC, if only by lack of endoscopists and dedicated blocks, it would be reasonable to propose a screening with virtual coloscopy. Its sensitivity and specificity for polyps of more than $1 \mathrm{~cm}$ may degenerate are excellent. In addition, this examination is easier to practice provided that radiologists with specific training are available. CTC has the dual advantage of being more sensitive and specific than stool tests and has better acceptability than optical colonoscopy. Indeed the latter is more invasive, with several negative examinations and causes a work stoppage at least on the day of the examination.

\section{Conclusion :}

Although easily preventable, CRC ranks second to lung cancer in terms of overall mortality. However, this situation could be reversed if screening tests to effectively detect advanced adenomas and early cancers were widely applied. In developing countries screening and diagnosis of CRC would be significantly improved by paying particular attention to the mastery of virtual colonoscopy coupled with excellent expertise of endoscopists.

The aging of the population, population growth and exposure to additional risk factors (westernization of our way of life) explain the likely increase in the incidence of CRCs. Training of virtual colonoscopy radiologists must be considered to meet this challenge. Virtual colonoscopy is fast and without contraindications or major complications. It must select subjects with abnormalities under a colonoscopy. It goes without saying that this strategy will only achieve its objectives if expert endoscopists and appropriate equipment are available. 


\title{
6. Conflict of intereststatement
}

We certify that there is no conflict of interest with any financial organization inthe subject matter or materials discussed in this manuscript.

\section{Authors' biography}

\author{
No Biography
}

\section{References}

1. Corrêa., R.d.S., et al., Rectal cancer survival in a Brazilian Cancer Reference Unit. JCOL, 2016. 36(4): p. 203-207.https://doi.org/10.1016/j.jcol.2016.04.015

2. Organization., W.H., International Agency for Research on Cancer (IARC). Available at: http://www-dep.iarc.fr/ Accessed December 3, 2011, 2011.

3. Jasperson, K.W., et al., Hereditary and familial colon cancer. Gastroenterology, 2010. 138(6): p. 2044-58. https://doi.org/10.1053/j.gastro.2010.01.054 PMid:20420945 PMCid:PMC3057468 4. Markowitz, S.D. and M.M. Bertagnolli, Molecular origins of cancer: Molecular basis of colorectal cancer. N Engl J Med, 2009. 361(25): p. 2449-60.

https://doi.org/10.1056/NEJMra0804588 PMid:20018966 PMCid:PMC2843693

5. [Consensus conference: Prevention Screening and Management of the Colonic Cancers. Paris, France, January 29-30, 1998. Proceedings]. Gastroenterol Clin Biol, 1998. 22(3 Suppl): p. S1-295. 6. National Comprehensive Cancer Network. NCCN clinical practice guidelines in oncology (NCCN guidelines): colorectal cancer screening.2016.

7. National Comprehensive Cancer Network. NCCN clinical practice guidelines in oncology (NCCN guidelines): colorectal cancer screening.2018.

8. Levin, B., et al., Screening and surveillance for the early detection of colorectal cancer and adenomatous polyps, 2008: a joint guideline from the American Cancer Society, the US MultiSociety Task Force on Colorectal Cancer, and the American College of Radiology.

Gastroenterology, 2008. 134(5): p. 1570-95. https://doi.org/10.1053/j.gastro.2008.02.002 PMid: 18384785

9. Moore, J.S. and T.H. Aulet, Colorectal Cancer Screening. Surg Clin North Am, 2017. 97(3): p. 487-502. https://doi.org/10.1016/j.suc.2017.01.001 PMid:28501242

10. Bibbins-Domingo, K., et al., Screening for Colorectal Cancer: US Preventive Services Task Force Recommendation Statement. JAMA, 2016. 315(23): p. 2564-2575.

https://doi.org/10.1001/jama.2016.5989 PMid:27304597

11. Winawer, S.J., et al., Risk of colorectal cancer in the families of patients with adenomatous polyps. National Polyp Study Workgroup. N Engl J Med, 1996. 334(2): p. 82-7.

https://doi.org/10.1056/NEJM199601113340204 PMid:8531963

12. Eaden, J.A., K.R. Abrams, and J.F. Mayberry, The risk of colorectal cancer in ulcerative colitis: a meta-analysis. Gut, 2001. 48(4): p. 526-35. https://doi.org/10.1136/gut.48.4.526 PMid:11247898 PMCid:PMC1728259

13. Farraye, F.A., et al., AGA medical position statement on the diagnosis and management of colorectal neoplasia in inflammatory bowel disease. Gastroenterology, 2010. 138(2): p. 738-45. https://doi.org/10.1053/j.gastro.2009.12.035 PMid:20141808

14. Tsaitas, C., A. Semertzidou, and E. Sinakos, Update on inflammatory bowel disease in patients with primary sclerosing cholangitis. World J Hepatol, 2014. 6(4): p. 178-87.

https://doi.org/10.4254/wjh.v6.i4.178 PMid:24799986 PMCid:PMC4009473

15. Wang, R. and R.W. Leong, Primary sclerosing cholangitis as an independent risk factor for colorectal cancer in the context of inflammatory bowel disease: a review of the literature. World $\mathrm{J}$ Gastroenterol, 2014. 20(27): p. 8783-9. 
16. Wells, K. and P.E. Wise, Hereditary Colorectal Cancer Syndromes. Surg Clin North Am, 2017. 97(3): p. 605-625. https://doi.org/10.1016/j.suc.2017.01.009 PMid:28501250

17. Lauby-Secretan, B., et al., The IARC Perspective on Colorectal Cancer Screening. N Engl J Med, 2018. 378(18): p. 1734-1740. https://doi.org/10.1056/NEJMsr1714643 PMid:29580179

18. Pox, C.P., Controversies in colorectal cancer screening. Digestion, 2014. 89(4): p. 274-81. https://doi.org/10.1159/000363287 PMid:25034478

19. Mohammed, M.F., et al., Trends in CT colonography: bibliometric analysis of the 100 mostcited articles. Br J Radiol, 2017. 90(1080): p. 20160755. https://doi.org/10.1259/bjr.20160755

20. Lin, J.S., et al., Screening for Colorectal Cancer: Updated Evidence Report and Systematic Review for the US Preventive Services Task Force. JAMA, 2016. 315(23): p. 2576-94. https://doi.org/10.1001/jama.2016.3332 PMid:27305422

21. Cancer Stat Facts: Colorectal Cancer. https://seer.cancer.gov/statfacts/html/colorect.html, 2018.

22. Winawer, S.J., et al., Prevention of colorectal cancer by colonoscopic polypectomy. The National Polyp Study Workgroup. N Engl J Med, 1993. 329(27): p. 1977-81.

https://doi.org/10.1056/NEJM199312303292701 PMid:8247072

23. Nishihara, R., et al., Long-term colorectal-cancer incidence and mortality after lower endoscopy. N Engl J Med, 2013. 369(12): p. 1095-105. https://doi.org/10.1056/NEJMoa1301969 PMid:24047059 PMCid:PMC3840160

24. Shaukat, A., et al., Long-term mortality after screening for colorectal cancer. N Engl J Med, 2013. 369(12): p. 1106-14. https://doi.org/10.1056/NEJMoa1300720 PMid:24047060

25. Longcroft-Wheaton, G., et al., High-definition vs. standard-definition colonoscopy in the characterization of small colonic polyps: results from a randomized trial. Endoscopy, 2012. 44(10): p. 905-10. https://doi.org/10.1055/s-0032-1310004 PMid:22893132

26. Pellise, M., et al., Impact of wide-angle, high-definition endoscopy in the diagnosis of colorectal neoplasia: a randomized controlled trial. Gastroenterology, 2008. 135(4): p. 1062-8. https://doi.org/10.1053/j.gastro.2008.06.090 PMid:18725223

27. Rastogi, A., et al., Randomized, controlled trial of standard-definition white-light, highdefinition white-light, and narrow-band imaging colonoscopy for the detection of colon polyps and prediction of polyp histology. Gastrointest Endosc, 2011. 74(3): p. 593-602.

https://doi.org/10.1016/j.gie.2011.04.050 PMid:21802078

28. Subramanian, V., et al., High definition colonoscopy vs. standard video endoscopy for the detection of colonic polyps: a meta-analysis. Endoscopy, 2011. 43(6): p. 499-505.

https://doi.org/10.1055/s-0030-1256207 PMid:21360420

29. Gralnek, I.M., et al., Standard forward-viewing colonoscopy versus full-spectrum endoscopy: an international, multicentre, randomised, tandem colonoscopy trial. Lancet Oncol, 2014. 15(3): p. 353-60. https://doi.org/10.1016/S1470-2045(14)70020-8

30. Adler, A., et al., Latest generation, wide-angle, high-definition colonoscopes increase adenoma detection rate. Clin Gastroenterol Hepatol, 2012. 10(2): p. 155-9.

https://doi.org/10.1016/j.cgh.2011.10.026 PMid:22056301

31. Papanikolaou, I.S., et al., Lower adenoma miss rate with FUSE vs. conventional colonoscopy with proximal retroflexion: a randomized back-to-back trial. Endoscopy, 2017. 49(5): p. 468-475. https://doi.org/10.1055/s-0042-124415 PMid:28107765

32. Rex, D.K. and M. Khashab, Colonoscopic polypectomy in retroflexion. Gastrointest Endosc, 2006. 63(1): p. 144-8. https://doi.org/10.1016/j.gie.2005.09.016 PMid:16377332

33. Pidala, M.J. and M.V. Cusick, The Difficult Colorectal Polyp. Surg Clin North Am, 2017. 97(3): p. 515-527. https://doi.org/10.1016/j.suc.2017.01.003 PMid:28501244

34. Morson, B., President's address. The polyp-cancer sequence in the large bowel. Proc R Soc Med, 1974. 67(6 Pt 1): p. 451-7.

35. Eide, T.J., Natural history of adenomas. World J Surg, 1991. 15(1): p. 3-6. https://doi.org/10.1007/BF01658952 PMid:1994603

36. Takayama, T., et al., Aberrant crypt foci of the colon as precursors of adenoma and cancer. $\mathrm{N}$ Engl J Med, 1998. 339(18): p. 1277-84. https://doi.org/10.1056/NEJM199810293391803

PMid:9791143

37. Rex, D.K., et al., Serrated lesions of the colorectum: review and recommendations from an expert panel. Am J Gastroenterol, 2012. 107(9): p. 1315-29; quiz 1314, 1330. 
38. Hassan, C., P.J. Pickhardt, and D.K. Rex, A resect and discard strategy would improve costeffectiveness of colorectal cancer screening. Clin Gastroenterol Hepatol, 2010. 8(10): p. 865-9, 869 e1-3. https://doi.org/10.1016/j.cgh.2010.05.018

39. Ignjatovic, A., et al., Optical diagnosis of small colorectal polyps at routine colonoscopy (Detect InSpect ChAracterise Resect and Discard; DISCARD trial): a prospective cohort study. Lancet Oncol, 2009. 10(12): p. 1171-8. https://doi.org/10.1016/S1470-2045(09)70329-8 40. Pickhardt, P.J., et al., Low rates of cancer or high-grade dysplasia in colorectal polyps collected from computed tomography colonography screening. Clin Gastroenterol Hepatol, 2010. 8(7): p. 610-5. https://doi.org/10.1016/j.cgh.2010.03.007 PMid:20304097

41. Eisen, G.M., et al., High-resolution chromoendoscopy for classifying colonic polyps: a multicenter study. Gastrointest Endosc, 2002. 55(6): p. 687-94.

https://doi.org/10.1067/mge.2002.123619 PMid:11979251

42. Machida, H., et al., Narrow-band imaging in the diagnosis of colorectal mucosal lesions: a pilot study. Endoscopy, 2004. 36(12): p. 1094-8. https://doi.org/10.1055/s-2004-826040 PMid:15578301

43. Singh, R., et al., Narrow-band imaging with dual focus magnification in differentiating colorectal neoplasia. Dig Endosc, 2013. 25 Suppl 2: p. 16-20. https://doi.org/10.1111/den.12075 44. Sano, Y., et al., Narrow-band imaging (NBI) magnifying endoscopic classification of colorectal tumors proposed by the Japan NBI Expert Team. Dig Endosc, 2016. 28(5): p. 526-33. https://doi.org/10.1111/den.12644 PMid:26927367

45. Kaminski, M.F., et al., Advanced imaging for detection and differentiation of colorectal neoplasia: European Society of Gastrointestinal Endoscopy (ESGE) Guideline. Endoscopy, 2014. 46(5): p. 435-49. https://doi.org/10.1055/s-0034-1365348 PMid:24639382

46. Rastogi, A., et al., High accuracy of narrow band imaging without magnification for the realtime characterization of polyp histology and its comparison with high-definition white light colonoscopy: a prospective study. Am J Gastroenterol, 2009. 104(10): p. 2422-30. https://doi.org/10.1038/ajg.2009.403 PMid:19584829

47. Rex, D.K., et al., The American Society for Gastrointestinal Endoscopy PIVI (Preservation and Incorporation of Valuable Endoscopic Innovations) on real-time endoscopic assessment of the histology of diminutive colorectal polyps. Gastrointest Endosc, 2011. 73(3): p. 419-22. https://doi.org/10.1016/j.gie.2011.01.023 PMid:21353837

48. Wanders, L.K., et al., Diagnostic performance of narrowed spectrum endoscopy, autofluorescence imaging, and confocal laser endomicroscopy for optical diagnosis of colonic polyps: a meta-analysis. Lancet Oncol, 2013. 14(13): p. 1337-47. https://doi.org/10.1016/S14702045(13)70509-6

49. Shahid, M.W., et al., Diagnostic accuracy of probe-based confocal laser endomicroscopy and narrow band imaging for small colorectal polyps: a feasibility study. Am J Gastroenterol, 2012. 107(2): p. 231-9. https://doi.org/10.1038/ajg.2011.376 PMid:22068663

50. Kuruvilla, N., et al., A prospective dual-center proof-of-principle study evaluating the incremental benefit of narrow-band imaging with a fixed zoom function in real-time prediction of polyp histology. Can we resect and discard? Gastrointest Endosc, 2015. 82(2): p. 362-9. https://doi.org/10.1016/j.gie.2015.01.014 PMid:25841577

51. Hayashi, N., et al., Endoscopic prediction of deep submucosal invasive carcinoma: validation of the narrow-band imaging international colorectal endoscopic (NICE) classification. Gastrointest Endosc, 2013. 78(4): p. 625-32. https://doi.org/10.1016/j.gie.2013.04.185 PMid:23910062

52. Hewett, D.G., et al., Validation of a simple classification system for endoscopic diagnosis of small colorectal polyps using narrow-band imaging. Gastroenterology, 2012. 143(3): p. 599-607 e1. https://doi.org/10.1053/j.gastro.2012.05.006

53. Graser, A., et al., Comparison of CT colonography, colonoscopy, sigmoidoscopy and faecal occult blood tests for the detection of advanced adenoma in an average risk population. Gut, 2009. 58(2): p. 241-8. https://doi.org/10.1136/gut.2008.156448 PMid:18852257

54. Johnson, C.D., et al., Accuracy of CT colonography for detection of large adenomas and cancers. N Engl J Med, 2008. 359(12): p. 1207-17. https://doi.org/10.1056/NEJMoa0800996 PMid:18799557 PMCid:PMC2654614 
55. Pickhardt, P.J., et al., Computed tomographic virtual colonoscopy to screen for colorectal neoplasia in asymptomatic adults. N Engl J Med, 2003. 349(23): p. 2191-200. https://doi.org/10.1056/NEJMoa031618 PMid:14657426

56. Mulhall, B.P., G.R. Veerappan, and J.L. Jackson, Meta-analysis: computed tomographic colonography. Ann Intern Med, 2005. 142(8): p. 635-50. https://doi.org/10.7326/0003-4819-1428-200504190-00013 PMid:15838071

57. Macari, M., et al., Colorectal neoplasms: prospective comparison of thin-section low-dose multi-detector row CT colonography and conventional colonoscopy for detection. Radiology, 2002. 224(2): p. 383-92. https://doi.org/10.1148/radiol.2242011382 PMid:12147833

58. Johnson, C.D., et al., Prospective blinded evaluation of computed tomographic colonography for screen detection of colorectal polyps. Gastroenterology, 2003. 125(2): p. 311-9.

https://doi.org/10.1016/S0016-5085(03)00894-1

59. Halligan, S., et al., Computed tomographic colonography: assessment of radiologist performance with and without computer-aided detection. Gastroenterology, 2006. 131(6): p. 16909. https://doi.org/10.1053/j.gastro.2006.09.051 PMid:17087934

60. Pescatore, P., et al., Diagnostic accuracy and interobserver agreement of CT colonography (virtual colonoscopy). Gut, 2000. 47(1): p. 126-30. https://doi.org/10.1136/gut.47.1.126 PMid:10861274 PMCid:PMC1727978

61. Cotton, P.B., et al., Computed tomographic colonography (virtual colonoscopy): a multicenter comparison with standard colonoscopy for detection of colorectal neoplasia. JAMA, 2004. 291(14): p. 1713-9. https://doi.org/10.1001/jama.291.14.1713 PMid:15082698

62. Hara, A.K., et al., Detection of colorectal polyps by computed tomographic colography: feasibility of a novel technique. Gastroenterology, 1996. 110(1): p. 284-90.

https://doi.org/10.1053/gast.1996.v110.pm8536869 PMid:8536869

63. Johnson, C.D., et al., Computerized tomographic colonography: performance evaluation in a retrospective multicenter setting. Gastroenterology, 2003. 125(3): p. 688-95.

https://doi.org/10.1016/S0016-5085(03)01058-8

64. Sosna, J., et al., CT colonography of colorectal polyps: a metaanalysis. AJR Am J Roentgenol, 2003. 181(6): p. 1593-8. https://doi.org/10.2214/ajr.181.6.1811593 PMid:14627580

65. Yee, J., et al., Colorectal neoplasia: performance characteristics of CT colonography for detection in 300 patients. Radiology, 2001. 219(3): p. 685-92.

https://doi.org/10.1148/radiology.219.3.r01jn40685 PMid:11376255

66. de Haan, M.C., et al., Diagnostic value of CT-colonography as compared to colonoscopy in an asymptomatic screening population: a meta-analysis. Eur Radiol, 2011. 21(8): p. 1747-63. https://doi.org/10.1007/s00330-011-2104-8 PMid:21455818 PMCid:PMC3128257

67. Halligan, S., et al., CT colonography in the detection of colorectal polyps and cancer: systematic review, meta-analysis, and proposed minimum data set for study level reporting. Radiology, 2005. 237(3): p. 893-904. https://doi.org/10.1148/radiol.2373050176 PMid:16304111 68. Hara, A.K., et al., Detection of colorectal polyps with CT colography: initial assessment of sensitivity and specificity. Radiology, 1997. 205(1): p. 59-65.

https://doi.org/10.1148/radiology.205.1.9314963 PMid:9314963

69. Laghi, A., et al., Detection of colorectal lesions with virtual computed tomographic colonography. Am J Surg, 2002. 183(2): p. 124-31. https://doi.org/10.1016/S0002-9610(01)008571

70. Summers, R.M., et al., Colonic polyps: complementary role of computer-aided detection in CT colonography. Radiology, 2002. 225(2): p. 391-9. https://doi.org/10.1148/radiol.2252011619 PMid:12409571

71. Petrick, N., et al., CT colonography with computer-aided detection as a second reader: observer performance study. Radiology, 2008. 246(1): p. 148-56.

https://doi.org/10.1148/radiol.2453062161 PMid:18096536

72. Yoshida, H. and J. Nappi, Three-dimensional computer-aided diagnosis scheme for detection of colonic polyps. IEEE Trans Med Imaging, 2001. 20(12): p. 1261-74.

https://doi.org/10.1109/42.974921 PMid:11811826

73. Yoshida, H., et al., Computer-aided diagnosis scheme for detection of polyps at CT colonography. Radiographics, 2002. 22(4): p. 963-79.

https://doi.org/10.1148/radiographics.22.4.g02j116963 PMid:12110726 
74. Summers, R.M., et al., Computed tomographic virtual colonoscopy computer-aided polyp detection in a screening population. Gastroenterology, 2005. 129(6): p. 1832-44. https://doi.org/10.1053/i.gastro.2005.08.054 PMid:16344052 PMCid:PMC1576342 75. Fidler, J.L., et al., Detection of flat lesions in the colon with CT colonography. Abdom Imaging, 2002. 27(3): p. 292-300. https://doi.org/10.1007/s00261-001-0171-z PMid:12173360 76. Pickhardt, P.J., et al., Flat colorectal lesions in asymptomatic adults: implications for screening with CT virtual colonoscopy. AJR Am J Roentgenol, 2004. 183(5): p. 1343-7. https://doi.org/10.2214/ajr.183.5.1831343 PMid:15505301

77. Taylor, S.A., et al., CT colonography: effect of experience and training on reader performance. Eur Radiol, 2004. 14(6): p. 1025-33. https://doi.org/10.1007/s00330-004-2262-z PMid: 14872280

78. Thomeer, M., et al., Patient acceptance for CT colonography: what is the real issue? Eur Radiol, 2002. 12(6): p. 1410-5. https://doi.org/10.1007/s003300101082

79. Stoop, E.M., et al., Participation and yield of colonoscopy versus non-cathartic CT colonography in population-based screening for colorectal cancer: a randomised controlled trial. Lancet Oncol, 2012. 13(1): p. 55-64. https://doi.org/10.1016/S1470-2045(11)70283-2 80. Vital signs: colorectal cancer screening test use--United States, 2012. MMWR Morb Mortal Wkly Rep, 2013. 62(44): p. 881-8.

81. Duarte, R.B., et al., Computed tomography colonography versus colonoscopy for the diagnosis of colorectal cancer: a systematic review and meta-analysis. Ther Clin Risk Manag, 2018. 14: p. 349-360. https://doi.org/10.2147/TCRM.S152147 PMid:29503554 PMCid:PMC5826249

82. van der Meulen, M.P., et al., Colorectal Cancer: Cost-effectiveness of Colonoscopy versus CT Colonography Screening with Participation Rates and Costs. Radiology, 2018. 287(3): p. 901911.https://doi.org/10.1148/radiol.2017162359 PMid:29485322

83. Sali, L. and D. Regge, CT colonography for population screening of colorectal cancer: hints from European trials. Br J Radiol, 2016. 89(1068): p. 20160517.

https://doi.org/10.1259/bjr.20160517

84. Scott, R.G., et al., Community-based screening by colonoscopy or computed tomographic colonography in asymptomatic average-risk subjects. Am J Gastroenterol, 2004. 99(6): p. 1145-51. https://doi.org/10.1111/j.1572-0241.2004.30253.x PMid:15180739

85. Sali, L., et al., Reduced and Full-Preparation CT Colonography, Fecal Immunochemical Test, and Colonoscopy for Population Screening of Colorectal Cancer: A Randomized Trial. J Natl Cancer Inst, 2016. 108(2). https://doi.org/10.1093/jnci/djv319

86. Callstrom, M.R., et al., CT colonography without cathartic preparation: feasibility study. Radiology, 2001. 219(3): p. 693-8. https://doi.org/10.1148/radiology.219.3.r01jn22693

PMid:11376256

87. Iannaccone, R., et al., Detection of colorectal lesions: lower-dose multi-detector row helical CT colonography compared with conventional colonoscopy. Radiology, 2003. 229(3): p. 775-81. https://doi.org/10.1148/radiol.2293021399 PMid:14657315

88. Iannaccone, R., et al., Computed tomographic colonography without cathartic preparation for the detection of colorectal polyps. Gastroenterology, 2004. 127(5): p. 1300-11. https://doi.org/10.1053/j.gastro.2004.08.025 PMid:15520999

89. Pickhardt, P.J., et al., Colorectal cancer: CT colonography and colonoscopy for detection-systematic review and meta-analysis. Radiology, 2011. 259(2): p. 393-405.

https://doi.org/10.1148/radiol.11101887 PMid:21415247 PMCid:PMC3079122

90. Kim, D.H., et al., CT colonography versus colonoscopy for the detection of advanced neoplasia. N Engl J Med, 2007. 357(14): p. 1403-12. https://doi.org/10.1056/NEJMoa070543 PMid:17914041

91. Sosna, J., et al., Colonic perforation at CT colonography: assessment of risk in a multicenter large cohort. Radiology, 2006. 239(2): p. 457-63. https://doi.org/10.1148/radiol.2392050287 PMid: 16543590

92. Pickhardt, P.J., et al., Screening for colorectal neoplasia with CT colonography: initial experience from the 1 st year of coverage by third-party payers. Radiology, 2006. 241(2): p. 417 25. https://doi.org/10.1148/radiol.2412052007 PMid:16982816 
93. Pineau, B.C., et al., Virtual colonoscopy using oral contrast compared with colonoscopy for the detection of patients with colorectal polyps. Gastroenterology, 2003. 125(2): p. 304-10. https://doi.org/10.1016/S0016-5085(03)00885-0

94. Patel, J.D. and K.J. Chang, The role of virtual colonoscopy in colorectal screening. Clin Imaging, 2016. 40(2): p. 315-20. https://doi.org/10.1016/j.clinimag.2015.07.009 PMid:26298421 95. Guinigundo, A., Is the Virtual Colonoscopy a Replacement for Optical Colonoscopy? Semin Oncol Nurs, 2018. 34(2): p. 132-136. https://doi.org/10.1016/j.soncn.2018.03.004

96. JE, I.J., et al., CT-Colonography vs. Colonoscopy for Detection of High-Risk Sessile Serrated Polyps. Am J Gastroenterol, 2016. 111(4): p. 516-22. https://doi.org/10.1038/ajg.2016.58 PMid:27021193

97. Kim, D.H., et al., Flat Serrated Polyps at CT Colonography: Relevance, Appearance, and Optimizing Interpretation. Radiographics, 2018. 38(1): p. 60-

74.https://doi.org/10.1148/rg.2018170110 PMid:29148927

98. Gluecker, T.M., et al., Extracolonic findings at CT colonography: evaluation of prevalence and cost in a screening population. Gastroenterology, 2003. 124(4): p. 911-6. https://doi.org/10.1053/gast.2003.50158 PMid:12671887

99. Hara, A.K., et al., Incidental extracolonic findings at CT colonography. Radiology, 2000. 215(2): p. 353-7. https://doi.org/10.1148/radiology.215.2.r00ap33353 PMid:10796907

100. Hellstrom, M., M.H. Svensson, and A. Lasson, Extracolonic and incidental findings on CT colonography (virtual colonoscopy). AJR Am J Roentgenol, 2004. 182(3): p. 631-8. https://doi.org/10.2214/ajr.182.3.1820631 PMid:14975961

101. Pickhardt, P.J., et al., Unsuspected extracolonic findings at screening CT colonography: clinical and economic impact. Radiology, 2008. 249(1): p. 151-9.

https://doi.org/10.1148/radiol.2491072148 PMid:18796673

102. Sawhney, T.G., et al., Computed Tomography Colonography Less Costly Than Colonoscopy for Colorectal Cancer Screening of Commercially Insured Patients. Am Health Drug Benefits, 2018. 11(7): p. 353-361.

103. Kriza, C., et al., An international review of the main cost-effectiveness drivers of virtual colonography versus conventional colonoscopy for colorectal cancer screening: is the tide changing due to adherence? Eur J Radiol, 2013. 82(11): p. e629-36.

https://doi.org/10.1016/j.ejrad.2013.07.019

104. Offermans, T., et al., Preoperative segmental localization of colorectal carcinoma: CT colonography vs. optical colonoscopy. Eur J Surg Oncol, 2017. 43(11): p. 2105-2111.

https://doi.org/10.1016/j.ejso.2017.09.016 PMid:28965706

105. Rockey, D.C., et al., Standards for gastroenterologists for performing and interpreting diagnostic computed tomographic colonography. Gastroenterology, 2007. 133(3): p. 1005-24. https://doi.org/10.1053/j.gastro.2007.06.001 PMid:17678924

106. Wolf, A.M.D., et al., Colorectal cancer screening for average-risk adults: 2018 guideline update from the American Cancer Society. CA Cancer J Clin, 2018. 68(4): p. 250-281.

https://doi.org/10.3322/caac.21457 PMid:29846947

107. Tutein Nolthenius, C.J., et al., Evolution of Screen-Detected Small (6-9 mm) Polyps After a 3-Year Surveillance Interval: Assessment of Growth With CT Colonography Compared With Histopathology. Am J Gastroenterol, 2015. 110(12): p. 1682-90.

https://doi.org/10.1038/ajg.2015.340 PMid:26482858

108. Obaro, A.E., D.N. Burling, and A.A. Plumb, Colon cancer screening with CT colonography: logistics, cost-effectiveness, efficiency and progress. Br J Radiol, 2018. 91(1090): p. 20180307. https://doi.org/10.1259/bjr.20180307

109. Faivre, J., et al., Reduction in colorectal cancer mortality by fecal occult blood screening in a French controlled study. Gastroenterology, 2004. 126(7): p. 1674-80.

https://doi.org/10.1053/j.gastro.2004.02.018 PMid:15188160

110. Allison, J.E., et al., Screening for colorectal neoplasms with new fecal occult blood tests: update on performance characteristics. J Natl Cancer Inst, 2007. 99(19): p. 1462-70.

https://doi.org/10.1093/jnci/djm150 PMid:17895475

111. Imperiale, T.F., Noninvasive screening tests for colorectal cancer. Dig Dis, 2012. 30 Suppl 2: p. 16-26. https://doi.org/10.1159/000341884 
112. van Rossum, L.G., et al., Random comparison of guaiac and immunochemical fecal occult blood tests for colorectal cancer in a screening population. Gastroenterology, 2008. 135(1): p. 8290. https://doi.org/10.1053/j.gastro.2008.03.040 PMid:18482589

113. Hol, L., et al., Screening for colorectal cancer: randomised trial comparing guaiac-based and immunochemical faecal occult blood testing and flexible sigmoidoscopy. Gut, 2010. 59(1): p. 628. https://doi.org/10.1136/gut.2009.177089 PMid:19671542

114. Guittet, L., et al., Comparison of a guaiac based and an immunochemical faecal occult blood test in screening for colorectal cancer in a general average risk population. Gut, 2007. 56(2): p.

210-4. https://doi.org/10.1136/gut.2006.101428 PMid:16891354 PMCid:PMC1856766

115. Parra-Blanco, A., et al., Diagnostic accuracy of immunochemical versus guaiac faecal occult blood tests for colorectal cancer screening. J Gastroenterol, 2010. 45(7): p. 703-12.

https://doi.org/10.1007/s00535-010-0214-8 PMid:20157748

116. Park, D.I., et al., Comparison of guaiac-based and quantitative immunochemical fecal occult blood testing in a population at average risk undergoing colorectal cancer screening. Am J Gastroenterol, 2010. 105(9): p. 2017-25. https://doi.org/10.1038/ajg.2010.179 PMid:20502450 117. Giorgi Rossi, P., et al., Impact of Screening Program on Incidence of Colorectal Cancer: A Cohort Study in Italy. Am J Gastroenterol, 2015. 110(9): p. 1359-66.

https://doi.org/10.1038/ajg.2015.240 PMid:26303133

118. Chiu, H.M., et al., Effectiveness of fecal immunochemical testing in reducing colorectal cancer mortality from the One Million Taiwanese Screening Program. Cancer, 2015. 121(18): p. 3221-9. https://doi.org/10.1002/cncr.29462 PMid:25995082 PMCid:PMC4676309

119. Kaminska, K., et al., Prognostic and Predictive Epigenetic Biomarkers in Oncology. Mol Diagn Ther, 2019. 23(1): p. 83-95. https://doi.org/10.1007/s40291-018-0371-7 PMid:30523565 PMCid:PMC6394434

120. Lamb, Y.N. and S. Dhillon, Epi proColon((R)) 2.0 CE: A Blood-Based Screening Test for Colorectal Cancer. Mol Diagn Ther, 2017. 21(2): p. 225-232. https://doi.org/10.1007/s40291-0170259-y PMid:28155091

121. Ahmed, D., et al., A tissue-based comparative effectiveness analysis of biomarkers for early detection of colorectal tumors. Clin Transl Gastroenterol, 2012. 3: p. e27.

https://doi.org/10.1038/ctg.2012.21

122. deVos, T., et al., Circulating methylated SEPT9 DNA in plasma is a biomarker for colorectal cancer. Clin Chem, 2009. 55(7): p. 1337-46. https://doi.org/10.1373/clinchem.2008.115808 PMid:19406918

123. Lofton-Day, C., et al., DNA methylation biomarkers for blood-based colorectal cancer screening. Clin Chem, 2008. 54(2): p. 414-23. https://doi.org/10.1373/clinchem.2007.095992 PMid:18089654

124. Wasserkort, R., et al., Aberrant septin 9 DNA methylation in colorectal cancer is restricted to a single CpG island. BMC Cancer, 2013. 13: p. 398. https://doi.org/10.1186/1471-2407-13-398 125. Wang, Y., P.M. Chen, and R.B. Liu, Advance in plasma SEPT9 gene methylation assay for colorectal cancer early detection. World J Gastrointest Oncol, 2018. 10(1): p. 15-22.

https://doi.org/10.4251/wjgo.v10.i1.15 PMid:29375744 PMCid:PMC5767789

126. Church, T.R., et al., Prospective evaluation of methylated SEPT9 in plasma for detection of asymptomatic colorectal cancer. Gut, 2014. 63(2): p. 317-25. https://doi.org/10.1136/gutjnl-2012304149 PMid:23408352 PMCid:PMC3913123

127. Johnson, D.A., et al., Plasma Septin9 versus fecal immunochemical testing for colorectal cancer screening: a prospective multicenter study. PLoS One, 2014. 9(6): p. e98238. https://doi.org/10.1371/journal.pone.0098238

128. Graser, A., et al., Magnetic resonance colonography for the detection of colorectal neoplasia in asymptomatic adults. Gastroenterology, 2013. 144(4): p. 743-750 e2.

https://doi.org/10.1053/j.gastro.2012.12.041

129. Mandel, J.S., et al., Reducing mortality from colorectal cancer by screening for fecal occult blood. Minnesota Colon Cancer Control Study. N Engl J Med, 1993. 328(19): p. 1365-71. https://doi.org/10.1056/NEJM199305133281901 PMid:8474513

130. Sullivan, J.F. and J.A. Dumot, Maximizing the Effectiveness of Colonoscopy in the Prevention of Colorectal Cancer. Surg Oncol Clin N Am, 2018. 27(2): p. 367-376.

https://doi.org/10.1016/j.soc.2017.11.009 PMid:29496095 
131. Schoen, R.E., et al., Colorectal-cancer incidence and mortality with screening flexible sigmoidoscopy. N Engl J Med, 2012. 366(25): p. 2345-57.

https://doi.org/10.1056/NEJMoa1114635 PMid:22612596 PMCid:PMC3641846

132. Zauber, A.G., et al., Colonoscopic polypectomy and long-term prevention of colorectalcancer deaths. N Engl J Med, 2012. 366(8): p. 687-96. https://doi.org/10.1056/NEJMoa1 100370 PMid:22356322 PMCid:PMC3322371

133. Martin-Lopez, J.E., et al., Comparison of the accuracy of CT colonography and colonoscopy in the diagnosis of colorectal cancer. Colorectal Dis, 2014. 16(3): p. O82-9.

https://doi.org/10.1111/codi.12506

134. Knudsen, A.B., et al., Estimation of Benefits, Burden, and Harms of Colorectal Cancer Screening Strategies: Modeling Study for the US Preventive Services Task Force. JAMA, 2016. 315(23): p. 2595-609. https://doi.org/10.1001/jama.2016.6828 PMid:27305518

PMCid:PMC5493310

135. Taylor, S.A., et al., Acceptance by patients of multidetector CT colonography compared with barium enema examinations, flexible sigmoidoscopy, and colonoscopy. AJR Am J Roentgenol, 2003. 181(4): p. 913-21. https://doi.org/10.2214/ajr.181.4.1810913 PMid:14500202

136. Senore, C., et al., Flexible Sigmoidoscopy and CT Colonography Screening: Patients' Experience with and Factors for Undergoing Screening-Insight from the Proteus Colon Trial. Radiology, 2018. 286(3): p. 873-883. https://doi.org/10.1148/radiol.2017170228 PMid:29040021 137. Akerkar, G.A., et al., Patient experience and preferences toward colon cancer screening: a comparison of virtual colonoscopy and conventional colonoscopy. Gastrointest Endosc, 2001. 54(3): p. 310-5. https://doi.org/10.1067/mge.2001.117595 PMid:11522970

138. de Wijkerslooth, T.R., et al., Reasons for participation and nonparticipation in colorectal cancer screening: a randomized trial of colonoscopy and CT colonography. Am J Gastroenterol, 2012. 107(12): p. 1777-83. https://doi.org/10.1038/ajg.2012.140 PMid:23211845

139. Pickhardt, P.J., Imaging and Screening for Colorectal Cancer with CT Colonography. Radiol Clin North Am, 2017. 55(6): p. 1183-1196. https://doi.org/10.1016/j.rcl.2017.06.009

PMid:28991559

140. Ferrucci, J.T., Colon cancer screening with virtual colonoscopy: promise, polyps, politics. AJR Am J Roentgenol, 2001. 177(5): p. 975-88. https://doi.org/10.2214/ajr.177.5.1770975 PMid:11641151

141. Pickhardt, P.J., et al., Cost-effectiveness of colorectal cancer screening with computed tomography colonography: the impact of not reporting diminutive lesions. Cancer, 2007. 109(11): p. 2213-21. https://doi.org/10.1002/cncr.22668 PMid:17455218

142. Ran, T., et al., Cost-effectiveness of Colorectal Cancer Screening Strategies-a Systematic Review. Clin Gastroenterol Hepatol, 2019. https://doi.org/10.1016/j.cgh.2019.01.014 143. Vijan, S., et al., The cost-effectiveness of CT colonography in screening for colorectal neoplasia. Am J Gastroenterol, 2007. 102(2): p. 380-90. https://doi.org/10.1111/j.15720241.2006.00970.x PMid:17156139 PMCid:PMC1861841

144. Ladabaum, U., K. Song, and A.M. Fendrick, Colorectal neoplasia screening with virtual colonoscopy: when, at what cost, and with what national impact? Clin Gastroenterol Hepatol, 2004. 2(7): p. 554-63. https://doi.org/10.1016/S1542-3565(04)00247-2 